\title{
New U-Pb Isotopic Data for Detrital Zircons from Metasedimentary Sequences of Northwestern Taimyr
}

\author{
V. B. Ershova ${ }^{a *}$, A. V. Prokopiev ${ }^{b}$, A. K. Khudoley ${ }^{a}$, V. F. Proskurnin ${ }^{c}$, T. Andersen ${ }^{d}$, K. Kullerud ${ }^{e}$, \\ M. A. Stepunina ${ }^{c}$, and D. A. Kolchanov ${ }^{a}$ \\ Presented by Academician Yu.M. Pushcharovsky January 23, 2015
}

Received February 6, 2015

\begin{abstract}
This work presents the $\mathrm{U}-\mathrm{Pb}$ (LA-ICP-MS) data of detrital zircons from metasedimentary sequences of northwestern Taimyr. An analysis of the youngest populations of detrital zircons testifies to the wide distribution of Cambrian sequences in the study area, but not Precambrian sequences as was considered earlier, and the need for a substantial revision of the stratigraphic scheme of this area. The detrital zircon age distribution shows that the Timan margin of the Baltic paleocontinent was a major provenance area of the Cambrian sediments in northern and northwestern Taimyr, as well as the coeval sediments of the Severnaya Zemlya archipelago.
\end{abstract}

DOI: $10.1134 / \mathrm{S} 1028334 \mathrm{X} 17060022$

\section{INTRODUCTION}

Three structural zones (from south to north) are distinguished within the Taimyr Peninsula: Southern Taimyr, Central Taimyr, and Northern Taimyr [1] (Fig. 1). The Southern Taimyr zone (or the Mesozoic orogenic belt) is composed by Paleozoic-Mesozoic sequences deformed to various degrees that had formed on the passive margin of the Siberian paleocontinent [2]. The Central Taimyr zone is a collage of Riphean island arc structures of various ages [1], accreted to the margin of the Siberian paleocontinent in the Neoproterozoic (Circum-Siberian orogenic belt [2]) and overlapped by the Vendian-Paleozoic sedimentary cover. The Northern Taimyr zone and structures of the Severnaya Zemlya archipelago comprise the Late Paleozoic Taimyr-Severnaya Zemlya orogenic belt [2]. The structural zones are bounded by large faults (or sutures): the Main Taimyr and Pyasina-Faddey (Fig. 1). The Northern Taimyr zone, the

\footnotetext{
${ }^{a}$ Institute of Earth Sciences, St. Petersburg State University, St. Petersburg, 199034 Russia

${ }^{b}$ Diamond and Precious Metal Geology Institute, Siberian Branch, Russian Academy of Sciences, Yakutsk, 677980 Russia

${ }^{c}$ Karpinsky All-Russia Research Geological Institute, St. Petersburg, 199106 Russia

${ }^{d}$ University of Oslo, Blindern, N-0316 Oslo, Norway

${ }^{e}$ University of Tromsø, $N$-9037, Tromsø, Norway

*e-mail: ershovavictoria@gmail.com
}

structures of the Severnaya Zemlya archipelago, and the northern part of the Kara Sea are referred to the so-called Kara terrane, which is the basement of the North Kara potential oil-and-gas bearing sedimentary basin. According to modern concepts, this terrain was accreted to the Siberian continent at the end of the Paleozoic (Late Carboniferous-Early Permian) [1, 3, 4] or in the Early Carboniferous [5, 6].

We performed $\mathrm{U}-\mathrm{Pb}$ dating of clastic zircons from three samples of metasandstones, collected within the Northern Taimyr structural zone (northwestern Taimyr Peninsula). The sedimentary sequences are represented by contrasting and lithologically highly variable, to varying degrees, metamorphosed rocks. The stratigraphic subdivision of these deposits is mainly based on rare finds of microphytolites and acritarchs. This is a reason for difficulties both in determination of the stratigraphic age of the sequences and in correlation of different facies deposits [7,8]. There are several different correlation schemes for metasedimentary complexes of the studied area, which are referred to the Precambrian, mainly the Late Riphean-Early Vendian [7, 8]. According to published geological maps [7, 8], samples were collected from Riphean-Vendian deposits of two different structural-facies zones, ascribed to four formations: Minin, Sterligov, and the unstratified Zhdanov and Oktyabrskii (Figs. 1, 2).

Preliminary sample preparation and extraction of zircons were carried out at the Institute of Precambrian Geology and Geochronology, Russian Academy 


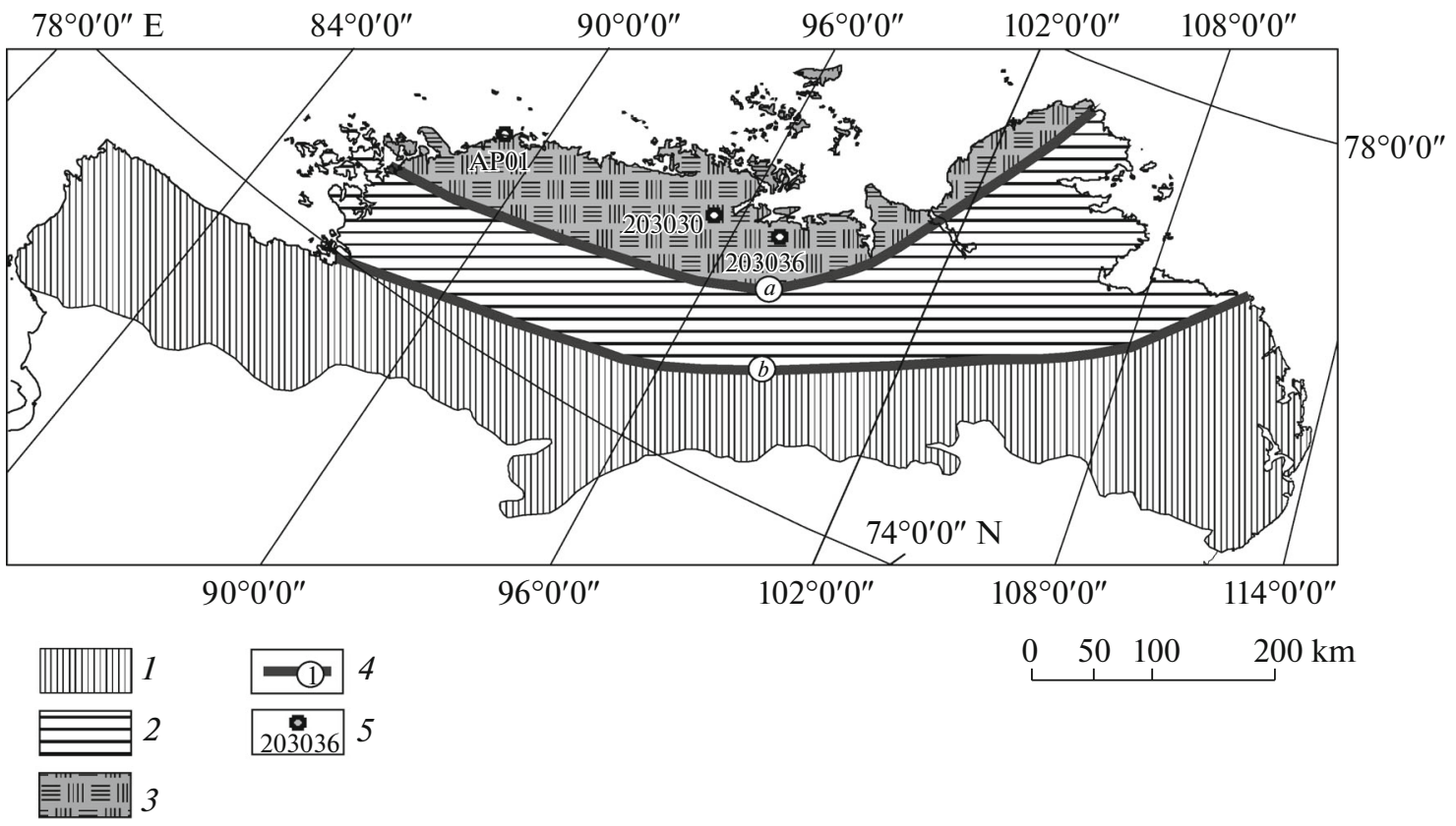

Fig. 1. Simplified tectonic scheme of the Taimyr Peninsula. 1, South Taimyr structural zone; 2, Central Taimyr structural zone; 3 , North Taimyr structural zone; 4, main faults ( $a$, Main Taimyr, $b$, Pyasina-Faddey); 5 , sampling sites and numbers of samples.

of Sciences (IPGG RAS) following the standard procedure. The U- $\mathrm{Pb}$ (LA-ICP-MS) dating of zircons was performed at the University of Oslo (Norway) on a Nu Plasma HR multicollector inductively-coupledplasma mass spectrometer equipped with a NewWave Research LUV213 laser microprobe. The analytical error of $\mathrm{U}-\mathrm{Pb}$ analyses is at the $\pm 1 \sigma$ level. The crystallization age of detrital zircons with an age of more than $1000 \mathrm{Ma}$ was calculated with respect to the ${ }^{207} \mathrm{~Pb} /{ }^{206} \mathrm{~Pb}$ ratio; the age of the younger zircons was calculated with respect to the ${ }^{206} \mathrm{~Pb} /{ }^{238} \mathrm{U}$ ratio. The detrital zircon age probability density distribution was plotted using the Isoplot 4.0 software [9]. The age, based on three or more dated grains, was determined using the Age Pick software developed at the University of Arizona (United States). The age distribution plots for detrital zircons from the examined samples are shown in Fig. 3.

The sample AP01 was collected from the Sterligov Formation, which is represented by intensely deformed rhythmically alternating metasandstones, metasiltstones, and phyllites, as well as subordinate interlayers and lenses of carbonaceous phyllites. Stratigraphically, the age of the Sterligov Formation was earlier determined as Riphean [8]. The sample contained zircons of Precambrian age $(71 \%)$, one Archean grain $(2533 \pm 19 \mathrm{Ma})$, and insignificant amounts of zircons of Paleoproterozoic $(2 \%)$ and Mesoproterozoic age $(8 \%)$. The Neoproterozoic zircon grains $(59 \%)$ are distinctly subdivided into several detrital zircon age populations with peaks of about 670, 650, 615, 595 and 565 Ma. Twenty-nine percent of zircons are of Paleozoic age (distinct peaks of 536 and $527 \mathrm{Ma}$ are attributed to the Early Cambrian). The age of young zircon populations allows us to conclude that these deposits accumulated not earlier than the Early Cambrian.

Sample 203030 was collected from the overlying Minin Formation, composed of rhythmically interbedded metasandstones, metasiltstones, and metamudstones. This sequence was ascribed to the late Riphean-Early Vendian based on the finds of microphytolites and its stratigraphic position in the succession below the Khutudin Formation, the upper part of which yielded fragments of poorly preserved trilobites [8]. Seventy-five percent of the zircons in the sample are of Precambrian age; $10 \%$ of zircons are Paleoproterozoic and Mesoproterozoic, and their ages are not grouped into distinct peaks. The dominating Neoproterozoic zircons $(65 \%)$ yield four peaks with ages of about 670,630, 595, and 560 Ma. Paleozoic zircon grains $(25 \%)$ yield a distinct peak of about $535 \mathrm{Ma}$, indicating a likely Early Cambrian or younger age of the Minin Formation.

Sample 203036 was collected from deposits attributed to the unstratified Zhdanov and Oktyabrskii formations of Central Taimyr, composed of metaconglomerates, metragravellites, metasandstones, metasiltstones, dolomites, carbonaceous phyllites, and schists. Limestones and quartzites occur in subordinate amounts. The age of the sequence was determined conditionally as Riphean [7]. Fifteen percent of clastic zircons extracted from this sample are of Paleoproterozoic age with distinct peaks of about 1735 and 


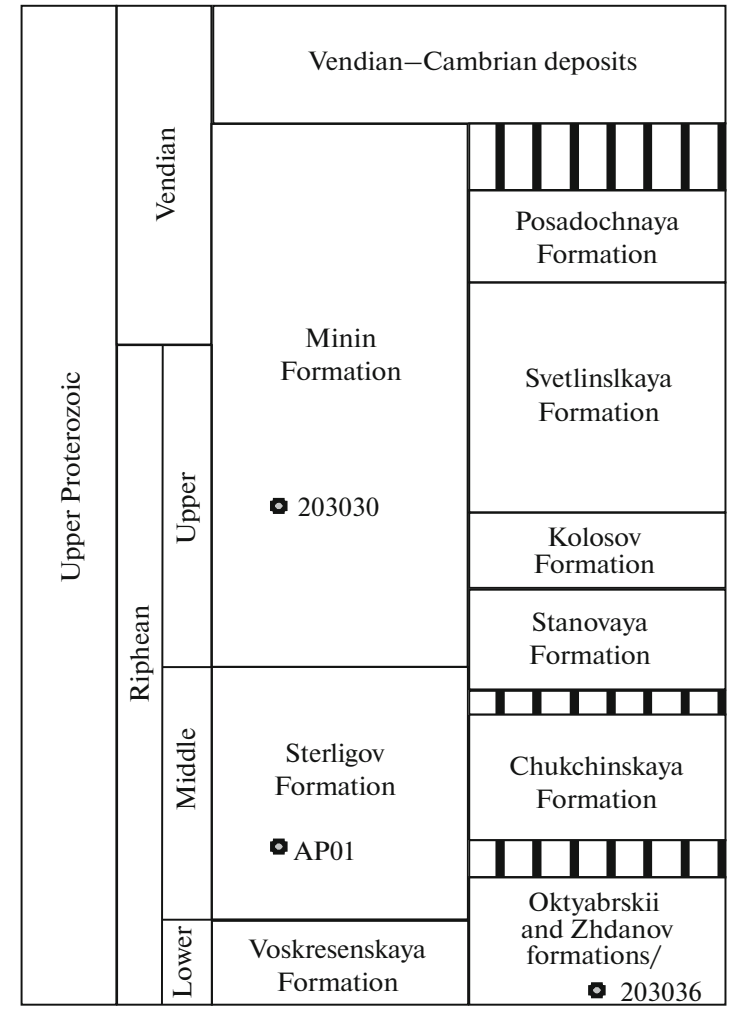

Fig. 2. Stratigraphic scheme of the northern Taimyr structural zone, simplified after [7,8].

1640 Ma. Mesoproterozoic zircon grains (16\%) are grouped into several populations with peaks of about 1525, 1440, and 1220 Ma. Zircons of Neoproterozoic age predominate (distinct peaks of about 670,625, and $555 \mathrm{Ma})$. The Early Paleozoic zircon grains (15\%) form two peaks: 523 and $492 \mathrm{Ma}$. Based on the age of the youngest peak, one can assume that, probably, this sequence was deposited in the Late Cambrian.

Similar age datings were obtained for detrital zircons from deposits common in the easternmost Northern Taimyr structural zone (Chelyuskin Cape) [10], where samples, taken from metasedimentary sequences previously attributed to the Precambrian, yielded young population of zircons of Early Cambrian age. The above-mentioned and our age datings indicate a wide distribution of Cambrian deposits in Northern Taimyr, which had previously been attributed to the Upper Precambrian, and the need for substantial revision of the age of metasedimentary rocks of the study area.

The new age datings of detrital zircons are very close to those obtained for zircons from the Cambrian deposits of the Severnaya Zemlya archipelago (Bolshevik and October Revolution islands) [11, 12]. The Cambrian deposits are strongly deformed, metamorphosed to varying degrees, and are overlapped with an angular unconformity by the less deformed Ordovician-Devonian sedimentary complex [13]. This
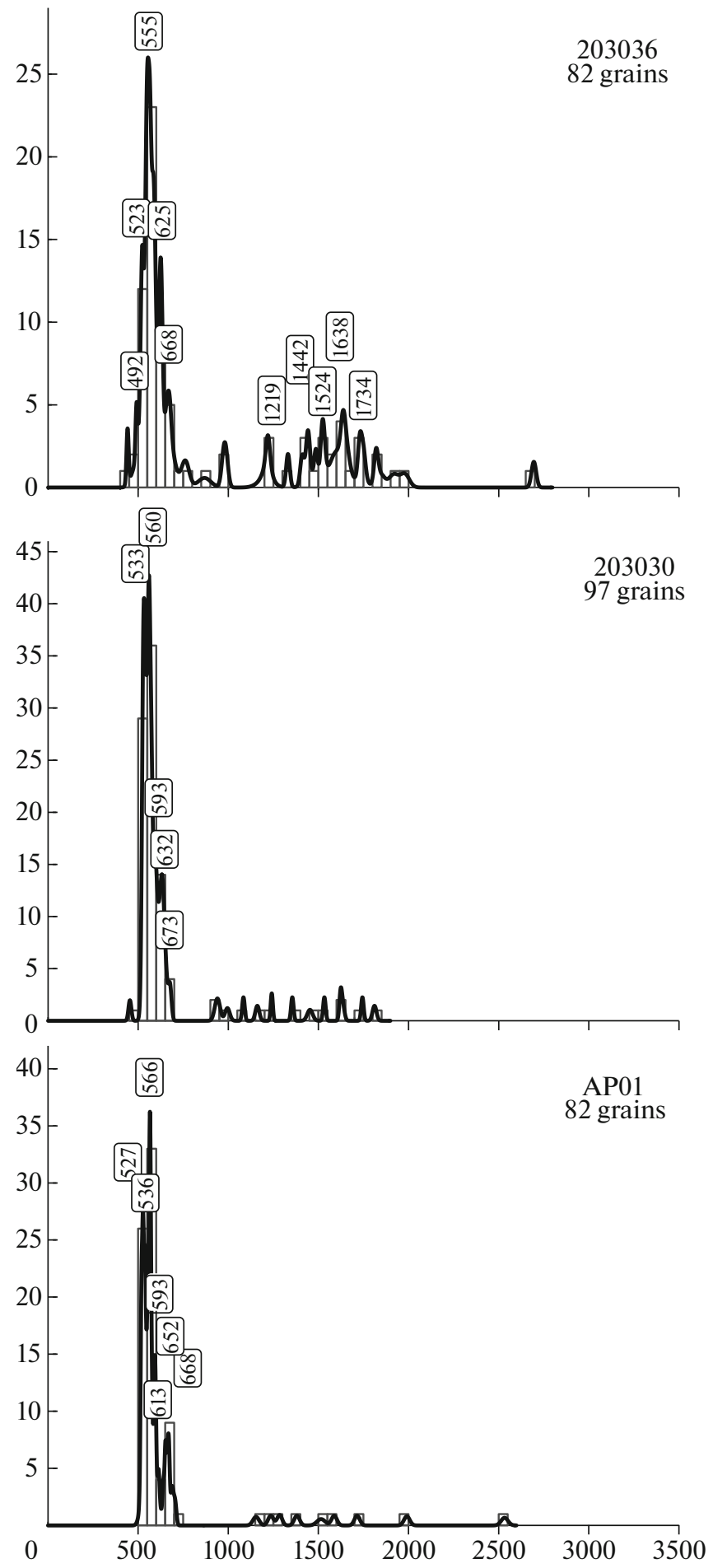

Fig. 3. Probability density plots and histograms of detrital zircon ages from the samples studied. Characters on the plot represent the age peaks based on at least three zircon grains.

allows us to state the conclusion that the fold basement of the Kara Terrane and, therefore, the basement of the North Kara Basin are of Cambrian age. The rocks cropping out in the North Taimyr structural zone are metamorphosed to a greater degree than coeval Cambrian sequences of the Severnaya Zemlya archipelago. 
This is probably because of their close proximity to the front of the Late Paleozoic collision zone between the Kara terrane and the northern margin of the Siberian continent, rather than to a more ancient age as was previously thought $[7,8]$.

Most of the Neoproterozoic and Early Cambrian peaks in the age distribution of detrital zircons are well correlated with magmatic events that took place in the Timan orogenic belt. Igneous and metamorphic rocks known within Fennoscandia [14] and SvecofennianGrenville orogen [15] could have been sources of more ancient Meso- and Paleoproterozoic zircons. Igneous rocks of this age are missing in the northern part of the Siberian craton. The above new age datings indicate that the provenance areas for the studied complexes were within the Baltic paleocontinent, but not the Siberian continent. This is in good agreement with the data obtained for the coeval complexes of the Severnaya Zemlya archipelago [13].

\section{CONCLUSIONS}

(1) The examined metasedimentary complexes of Northern Taimyr are much younger than was previously thought, and are not older than the Cambrian.

(2) There is a necessity for a substantial revision of the existing stratigraphic schemes developed for the Northern Taimyr, based on both traditional biostratigraphic and precision isotope-geochronological studies.

(3) The Timan margin of the Baltic paleocontinent is considered to be the main provenance area for the Cambrian sediments of the Northern Taimyr, as well as coeval deposits of the Severnaya Zemlya archipelago, which is confirmed by the paleomagnetic data demonstrating the exotic origin of the Kara terrane with respect to the Siberian continent [8].

\section{ACKNOWLEDGMENTS}

This work was supported in part by the Russian Foundation for Basic Research (project nos. 13-0500700 and 13-05-00943), St. Petersburg State University (project no. 3.38.137.2014), the Diamond and Precious Metal Geology Institute, Siberian Branch, Russian Academy of Sciences (project no. VIII.66.1.4), Program no. 53 of the Presidium of the Russian Academy of
Sciences (project no. 44P, SIU no. CPRU-2011/10106), and the applied research project RFMEFI57614X0052.

\section{REFERENCES}

1. V. A. Vernikovsky, Geodynamic Evolution of Taimyr Folded Region (Trofimuk Inst. Petrol. Geol. Geophys., Siberian Branch Russ. Acad. Sci., Novosibirsk, 1996) [in Russian].

2. L. M. Parfenov, N. A. Berzin, A. I. Khanchuk, et al., Tikhookean. Geol., No. 6, 7-42 (2003).

3. D. V. Metelkin, V. A. Vernikovsky, A. Yu. Kazansky, et al., Tectonophysics 398, 225-243 (2005).

4. L. R. M. Cocks and T. H. Torsvik, Earth-Sci. Rev. 82, 29-74 (2007).

5. V. B. Ershova, A. K. Khudoley, and A. V. Prokopiev, Geotectonics 47 (2), 93-100 (2013).

6. A. V. Prokopiev, V. B. Ershova, E. L. Miller, et al., Russ. Geol. Geophys., vol. 54, no. 10, pp. 1195-1204.

7. State Geological Map of the Russian Federation 1:1000000, the 3rd Generation, Sheet No. S-47-49Taimyr Lake, Explanatory Note, Ed. by Yu. E. Pogrebitskii and N. K. Shanurenko (Karpinsky Russ. Geol. Res. Inst., St. Petersburg, 1998).

8. State Geological Map of the Russian Federation 1:1000000, the 3rd ed., Sheet no. S-44-46-Ust-Tareya, Explanatory Note, Ed. by Yu. E. Pogrebitskii and B. G. Lopatin (Karpinsky Rus. Geol. Res. Inst., St. Petersburg, 2000).

9. K. R. Ludwig, User's Manual for ISOPLOT/Ex. Ver. 3.00. A Geochronological Toolkit for Microsoft Excel. Berkeley Geochronological Center Special Publication (Berkeley Geochronol. Center, Berkeley, CA, 2003).

10. V. Pease and R. A. Scott, J. Geol. Soc. (London, U. K.) 166, 517-527 (2009).

11. H. Lorenz, D. G. Gee, and A. Simonetti, Norw. J. Geol. 88 (4), 235-258 (2008).

12. A. A. Makar'ev and E. M. Makar'eva, Razved. Okhr. Nedr, No. 8, 71-77 (2012).

13. H. Lorenz, D. G. Gee, and M. Whitehous, Geol. Mag. 144, 105-125 (2007).

14. R. Lahtinen, A. A. Garde, and V. A. Melezhik, Episodes 31 (1), 20-28 (2008).

15. H. Lorenz, D. G. Gee, A. N. Larionov, et al., Geol. Mag. 149 (5), 875-891 (2012).

Translated by D. Voroshchuk 